\title{
Asian E-Commerce Engages Global Trade Openness: The Role of Information and Communications Technology, Social, and Security Indicators
}

Ika Yuni Wulansari ${ }^{a^{*}}$, Novia Budi Parwanto ${ }^{\mathrm{b}}$, ${ }^{\mathrm{a}, \mathrm{b}}$ Statistics Department, Politeknik Statistika STIS, East Jakarta, DKI Jakarta, 13330, Indonesia, Email:

a*ikayuni@stis.ac.id

E-commerce, as part of the digital economy, opens an opportunity to increase trade openness and economic growth. Asian e-commerce grows up fast recently, engaging global trade openness. Significant issues on boosting trade openness are lack of trust of social and security, and lack of access to ICT. This research aims to analyze the role of ICT, social and security indicators on trade openness among Asian countries. We used social and security indicators such as interpersonal safety and trust, quality of life, and crime. Meanwhile, ICT indicators used are secure internet servers, fixed telephone subscriptions, fixed broadband subscriptions, and mobile-cellular subscriptions. Panel data analysis is carried using series from 2012 to 2017 among 17 Asian countries. Asian countries experienced rapid trade openness growth since 2016, dominated by Hongkong and Singapore. Fixed telephone subscriptions and fixed broadband subscription have a positive and significant impact on trade openness. This is because, in 17 Asian countries which are dominated by emerging countries, the use of fixed telephone and fixed broadband is the main focus. Crime also has a significant impact to trade openness. Interpersonal safety and trust, as well as quality of life indicator, have a positive sign. However, both of these variables are statistically not significant.

Key words: ICT, Asian Countries, Crime, Trust, Trade Openness. 
International Journal of Innovation, Creativity and Change. www.ijicc.net

Volume 11, Issue 12, 2020

\section{Introduction}

Electronic commerce (E-Commerce) is a powerful concept and process that has fundamentally changed the current of human life. Electronic commerce is one of the main criteria of revolution of Information Technology and Communication (ICT) in the field of economy. In which, due to the enormous benefits that can be acquired, this trading style has spread rapidly. Certainly, it can be claimed that electronic commerce removes many limitations of traditional business.

E-Commerce engages global trade openness. Trade openness is the ratio of trade to GDP - an indicator of trade 'openness' - as a reflection of globalization and trade liberalization. It is argued that trade openness brings many economic benefits, including increased technology transfer, transfer of skills, increased labour and total factor productivity and economic growth and development.

Asia is home to 3.5 billion people, GDP per capita is currently 6,799 USD and expected to reach 8,897 USD by 2021. In Europe itself, a number of attractive e-commerce markets have been available provided by across countries, from Malaysia and Phillippines who are less obvious opportunities to apparent opportunities such as India and China. In Asia, about 993 million people have been doing online shopping nowadays, in which in 2021 as many as 454 million are expected to be new users. In sums, by 2021, there will be about 1.4 billion of ecommerce users, this number represents about $53 \%$ of the total population. (Statista, 2017).

The Internet penetration in Asia is $48 \%$ nowadays, in which in 2021 is expected to reach $59 \%$ by 2021 . Whilst, the penetration of smartphone is 35\% and should be grown to $44 \%$ by 2021 . These numbers might seem daunting, but Asia is a massive region and has a lot of opportunities for e-commerce to grow as Asia is most densely populated markets, in which the penetration of smartphone might surpass globally. In addition, $48 \%$ of online shoppers in Asia prefer to shop online via desktop, which is lower than the global average, $19 \%$ of online shoppers use mobile, and 25\% claim to have no preference (Statista, 2017). ICT plays a massive role in the growth of e-commerce towards trade openness in the Asia region.

Given the position of trade openness in the world as seen in Figure 1, among the top ten countries with the highest trade openness, there are four Asian countries, namely Hong Kong, Singapore, Vietnam, and the UA Emirates according to World Bank (WorldBank, 2017). More specifically in Asia, as seen in Figure 2, the top ten countries with the highest trade openness values are Hong Kong, Singapore, Vietnam, UA Emirates, Bahrain, Maldives, Malaysia, Cambodia, Palau, and Thailand. 
International Journal of Innovation, Creativity and Change. www.ijicc.net Volume 11, Issue 12, 2020

Figure 1. Rank of Trade Openness (\%) of 30 Figure 2. Rank of Trade Openness (\%) of Countries in the World, 2017 30 Countries in Asia, 2017

1. Luxembourg
2. Hong Kong
3. Singapore
4. Malta
5. Ireland
6. Vietnam
7. Seychelles
8. Slovakia
9. UA Emirates
10. Belgium
11. Hungary
12. R. of Congo
13. Lithuania
14. Slovenia
15. Netherlands
16. Czech Rep.
17. Estonia
18. Aruba
19. Bahrain
20. Maldives
21. Malaysia
22. Belarus
23. Cyprus
24. Bulgaria
25. Suriname
26. Somalia
27. Mauritania
28. Cambodia
29. Macedonia
30. Palau
(a)

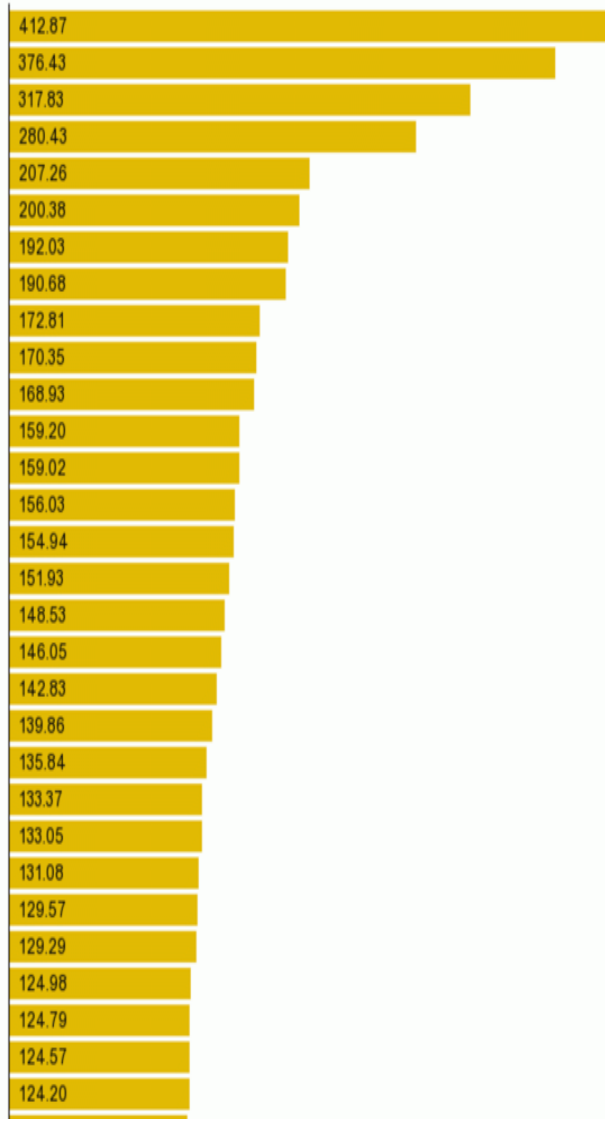

1. Hong Kong
2. Singapore
3. Vietnam
4. UA Emirates
5. Bahrain
6. Maldives
7. Malaysia
8. Cambodia
9. Palau
10. Thailand
11. Mongolia
12. Macao
13. Georgia
14. Oman
15. Kyrgyzstan
16. Kuwait
17. Jordan
18. Azerbajian
19. Qatar
20. Armenia
21. South Korea
22. Bhutan
23. Laos
24. Palestine
25. Iraq
26. Lebanon
27. Philippines
28. Saudi Arabia
29. Kazakhstan
30. Israel

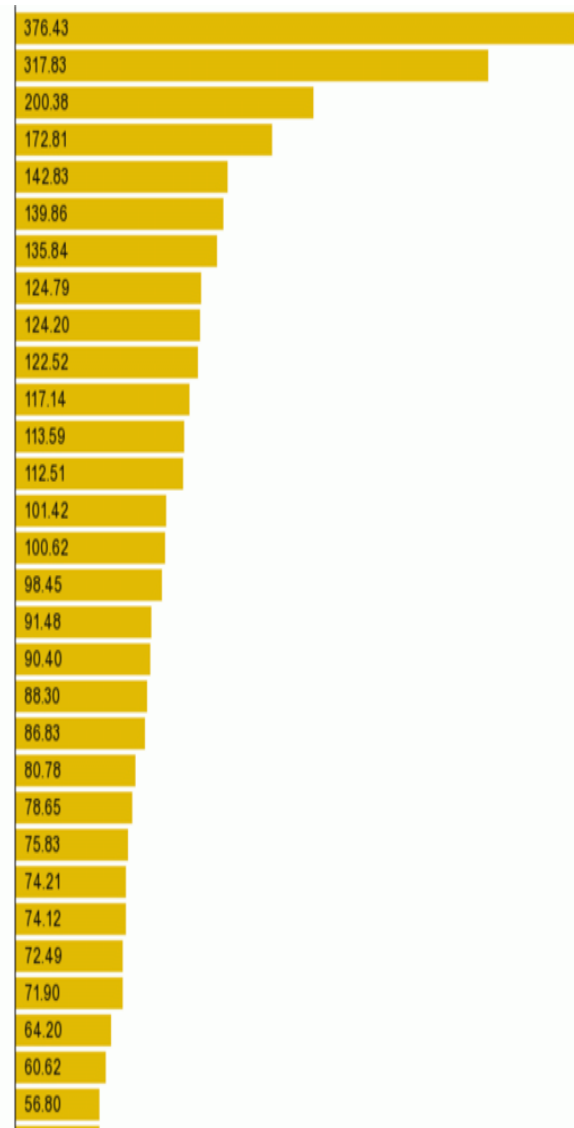

Trade openness in Asia, the average for 2017 was 95.19 percent. The highest value was in Hong Kong (376.43 percent), and the lowest value was in Pakistan. Significant issues on boosting trade openness are lack of trust of social and security, and lack of access to ICT. The visualization in Figure 3 gives evidence of the correlation between trust and GDP per capita. The variable of trust here is the share of people agreeing with the statement "most people can be trusted". Every dot on the scatter-plot corresponds to a different country. As it can be seen, there is a very strong positive relationship. 
International Journal of Innovation, Creativity and Change. www.ijicc.net Volume 11, Issue 12, 2020

Figure 3. Trust vs GDP per Capita in The World, 2014

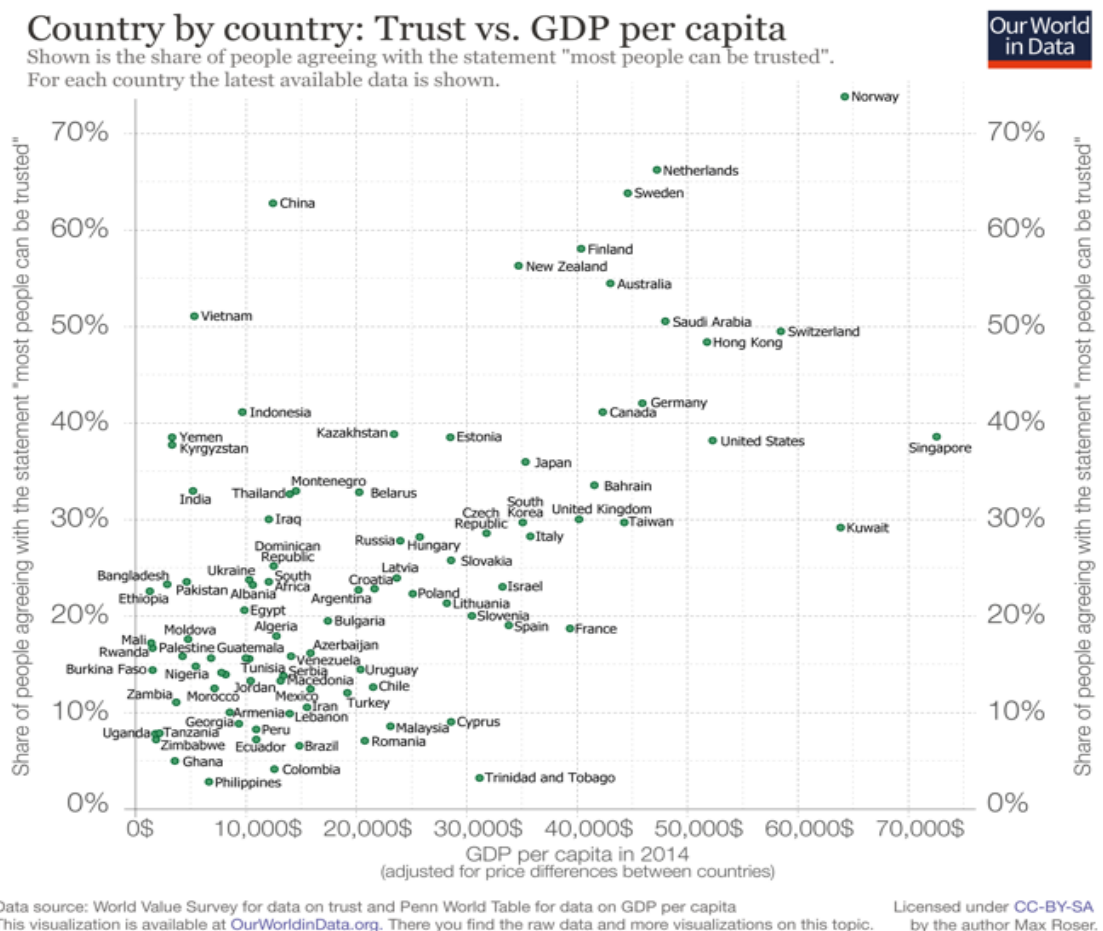

The interesting thing is that in Asian countries, trust rates are relatively higher compared to other regions, except for European countries (Figure 4).

Figure 4. Interpersonal Trust Attitudes in The World, 2014

Interpersonal trust attitudes, 2014

Share of people agreeing with the statement "most people can be trusted" (World Value Survey).

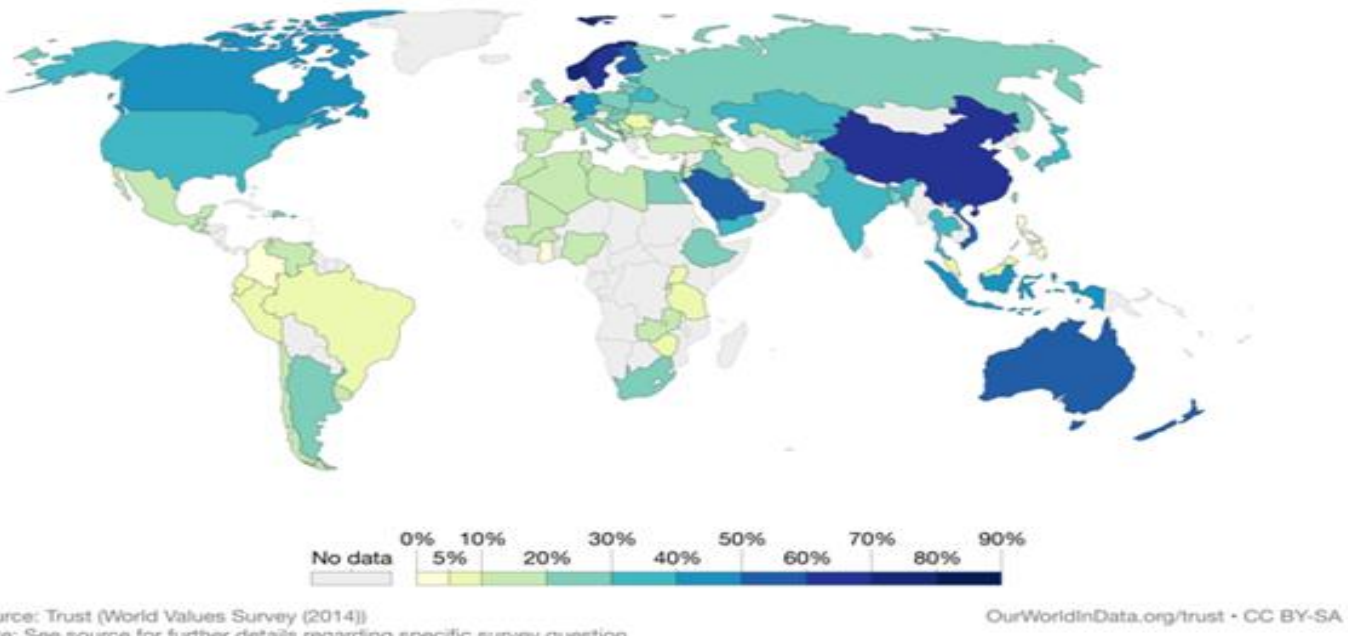

On the other hand, GDP per capita Asian countries are still around the world average with inequality, which is still relatively high (Figure 5). This is interesting to study the influence of 
International Journal of Innovation, Creativity and Change. www.ijicc.net Volume 11, Issue 12, 2020

social factor (trustworthy) on economic growth in the Asian region, where one indicator of economic growth is trade openness.

Figure 5. Interpersonal Trust vs Income Inequality, 2014

Interpersonal trust vs. income inequality, 1998

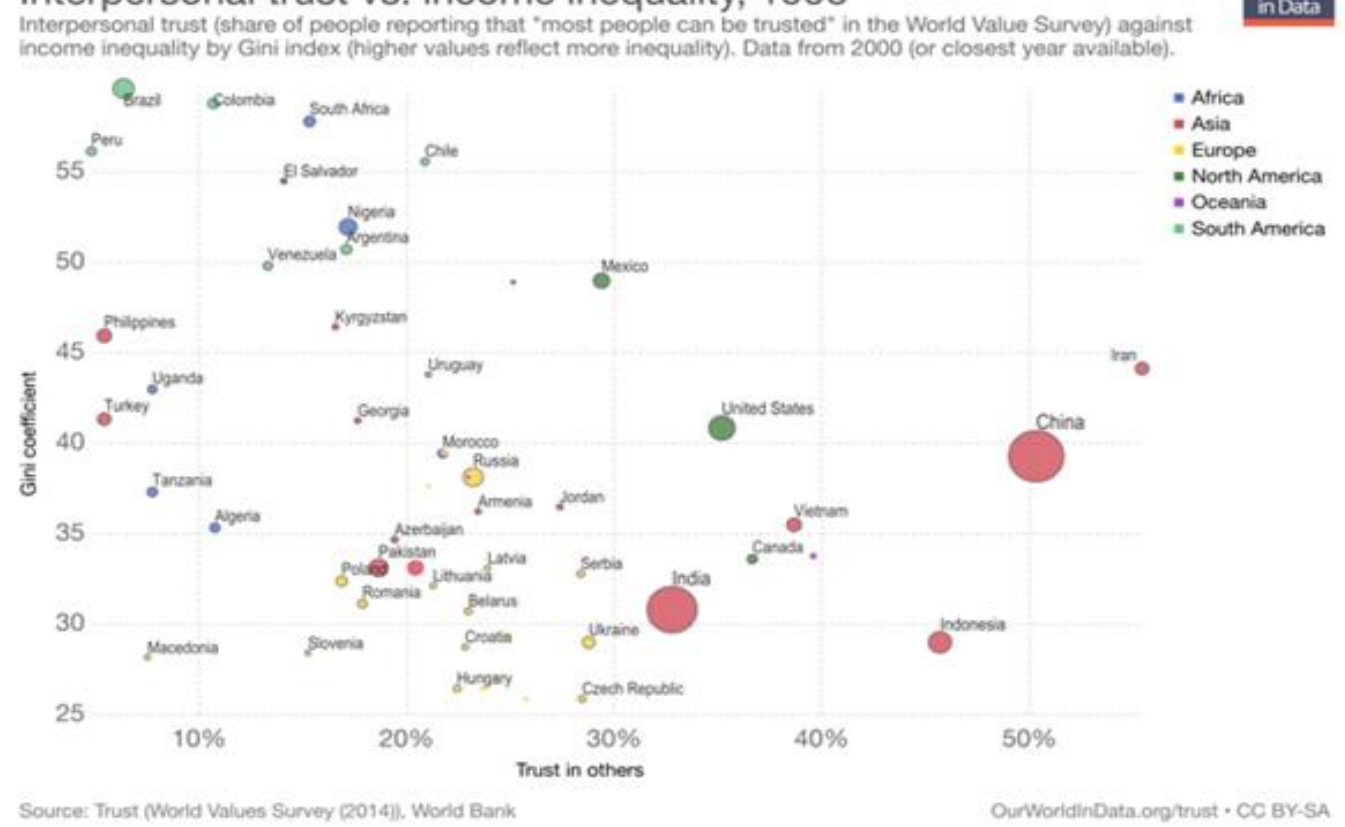

(Dollar \& Kraay, 2004) analyze the relationship between openness to trade and economic growth and conclude that developing countries benefit the most from opening their economies to the external world, by having an increase in GDP per capita. This study aims to analyze what is the impact of ICT and social indicators (interpersonal safety and trust index, quality of life index, and crime index) on the openness to trade in the Asian region. Openness to trade is another imperative determinant of economic growth. It is measured by dividing the sum of imports and exports of goods and services to GDP, and it affects economic growth by increasing the competitive advantage. Moreover, trade enhances the transfer of knowledge and technology.

\section{Literature Review}

Openness to Trade is defined as trade, which is the sum of imports and exports of goods and services, and it is computed as a percentage of GDP (WorldBank, 2017). Trade and market openness has historically gone hand-in-hand with better economic performance in countries at all levels of development, creating new opportunities for workers, consumers and firms globally, and help to eradicate poverty. A relatively open economy grows faster than a relatively closed one, salaries and working conditions are generally better in companies that 
International Journal of Innovation, Creativity and Change. www.ijicc.net Volume 11, Issue 12, 2020

trade than in countries that do not. More prosperity and opportunities throughout the world also help promote greater stability and security for everyone (OECD, 2019).

(Nath \& Liu, 2012) examine the effects of information and communications technology (ICT) on international trade in emerging markets. Their study used panel data from 1995 to 2010 for 40 emerging market economies (EMEs). The estimated fixed effects models of exports and imports with ICT as the primary explanatory variable of interest. ICT variables include growth in telecommunications investment, international internet bandwidth, internet subscriptions per 100 people, and the number of Internet hosts per 100 people. The first two variables represent ICT infrastructure, while the last two variables represent ICT use. They use a share of total exports and total imports in GDP as the dependent variable. Empirical results indicate that internet subscriptions and internet hosts have a significant positive impact on the export and import of shares in EME. Thus, the enhancing trade effect of ICT does not depend on ICT infrastructure but on its use. The results suggest that policies to encourage the use of ICT would have a positive impact on trade in EMEs. In the 20th century, followed by two new trends, fundamental economic structural changes occurred by which superior economic structures were expected to arise. These two trends include 1) globalization, in which some new markets are being introduced and 2) the revolution in ICT. ICT can decrease the economic barrier between countries, thereby increase foreign trade and openness to trade (trade liberalization).

Social factors such as feeling trust and secure play important role in engaging trade openness. In many articles, (Arrow, 1972) says that "virtually every commercial transaction has an element of trust, of course, transactions are carried out over a certain period of time". The extent to which trust is related to economic development has been the subject of many academic papers in the economic literature on growth (see (Algan \& Cahuc, 2010; Guiso, Sapienza, \& Zingales, 2006), and the references therein. A general way to get the first-level approach to this relationship is to estimate the correlation between trust and GDP per capita

Quality of Life index is one of social indicator that reflects economic well-being. Wellbeing societies/countries have more significant opportunities to engage in trade openness. The quality of life (QoL) has attracted a lot of attention in recent years and is increasingly becoming the object of theoretical and empirical research in various disciplines. The study of the concept is based on a fundamental assumption: the acceptance that the social and physical environment of an area can influence the well-being of people residing in that area. (Lambiri, Biagi, \& Royuela, 2007) argued that QoL is increasingly becoming a concept researched empirically and theoretically in the field of economics. In the urban economy, in particular, this increased interest stems primarily from the fact that quality of life affects urban competitiveness and urban growth: research shows that when households and businesses 
International Journal of Innovation, Creativity and Change. www.ijicc.net Volume 11, Issue 12, 2020

decide where to look, quality of life considerations can play a significant role. (Hall, 1995) argues that: 'Since the sources of the new economic growth are so various and finally perhaps so fickle, the possibilities are endless. But one central element is quality of life". In mainstream economics, QoL is associated with the concept of social well-being and traditionally has been mainly linked with monetary factors such as GDP. However, economic thinking moved away from this simplistic vision of QoL towards more complex definitions. The work of economists such as (Townsend, 1979) and the so-called Scandinavian Welfare Approach (Erikson, 1993; Erikson, Hansen, Uusitalo, \& Ringen, 1987) highlights the multidimensionality of QoL as an economic good. The increasing importance of QoL as an explanatory variable of different phenomena examined by economics and urban economics has led to the need for precise and objective measurements of it. The measuring method is the construction of composite indices to capture as precisely as possible the multidimensionality of the concept. In this study, we used QoL index from Numbeo surveys (Numbeo, 2017). Numbeo collects these data from a sample of cities in the world: Cost of living and purchasing power, Affordability of housing, Pollution including air, water, etc., Safety rates, Health system quality, and Traffic (commute times).

Crime also affects openness to trade. Governments are first of all concerned of their human capital, and before engaging in trade, one government would seek for countries where their trading agents would be relatively safe. Therefore high crime rates might constrain the effect of openness to trade, by generating a price mark-up similar to a hidden tax (J. E. Anderson \& Marcouiller, 2002). It can be noticed that the relationship between crime, trade openness, and economic growth is a growing concern and the interest for it is increasing. The amount of studies, which examine this relationship to assess the impact of crime on economic progress, is growing. Despite that, the results indicate that a clear conclusion on the association between them has not been defined. Many studies report that crime has a very significant negative influence on economic growth (Cárdenas, 2001; Gaibulloev \& Sandler, 2008; Peri, 2004), whereas other conclude that the effect is unclear (Burnham, Feinberg, \& Husted, 2004; Goulas \& Zervoyianni, 2013) or even absent (Chatterjee \& Ray, 2009; Mauro \& Carmeci, 2007).

In many research, trade openness and economic growth can be influenced by crime. (Adekoya \& Razak, 2017) using Nigeria series data 1970-2013, results that crime affects economic growth at a $1 \%$ and $10 \%$ level of significance. In the literature, the economic losses combined with the loss of human lives and property in Nigeria are often mentioned. The Federal Government of Nigeria in 2014 claimed that theft, fraud, corruption, and violence constituted a major challenge on the economy and financial budget. The relationship between crime and economic growth has gained in importance in the academic literature, and many tried to estimate what are the direct and indirect costs of crime on the society (McCollister, French, \& Fang, 2010). 
International Journal of Innovation, Creativity and Change. www.ijicc.net Volume 11, Issue 12, 2020

The amount of studies, which examine this relationship to assess the impact of crime on economic progress and trade openness, is growing. Despite that, the results indicate that a clear conclusion on the association among them has not been defined. Crime has an impending negative effect on human and capital stock, which are the crucial economic determinants because it decreases both the tangible and intangible welfare of individuals and the societies as a whole (D. A. Anderson, 1999; McCollister et al., 2010). As previously mentioned, technological change and FDI inflow are highly dependent on human and capital stock. Therefore the impact of crime on the latter group of determinants expands first to set as well, which in turn has an aggregate effect on trade openness and economic growth. Moreover, crime has a direct impact on FDI inflows acting as a deterrent for foreign investors (Daniele \& Marani, 2011; Gaibulloev \& Sandler, 2008) so it can inhibit trade openness. In this paper, crime is studied as a cause and not a consequence of the trade openness.

\section{Methodology}

\section{Data Sources}

ICT as E-commerce indicators that we used are secure internet servers, fixed telephone subscriptions, fixed broadband subscriptions, and mobile-cellular subscriptions. These data taken from E-Trade indicator of World Integrated Trade Solutions (WITS) and International Telecommunication Union (ITU).

Interpersonal security and trust using data on general social trust from various surveys, trust indicators such as the degree of victimization of reported crime, survey responses about feelings of safety and security in one's environment, data about incidents of murder, and the risk of reporting possible physical assault, extortion, or robbery. This is from Afrobarometer, Asian Barometer, World Values Survey.

Meanwhile, quality of life and crime index are taken from Numbeo surveys (Numbeo, 2017). Numbeo collects these data from a sample of cities in the world: Cost of living and purchasing power, Affordability of housing, Pollution including air, water, etc., Safety rates, Health system quality, and Traffic (commute times). Due to data incompleteness, the data used in this study are collected from 2012 to 2017 in 17 Asian Countries.

\section{Data Analysis}

We use balanced panel data analysis to estimate the impact of ICT indicators (secure internet servers, fixed telephone subscriptions, fixed broadband subscriptions, and mobile-cellular subscriptions) and social indicators (interpersonal safety and trust, quality of life, and crime) 
International Journal of Innovation, Creativity and Change. www.ijicc.net Volume 11, Issue 12, 2020

on trade openness in the Asian region. We use the standard production function model. In this paper, trade openness is represented by the production function as follow:

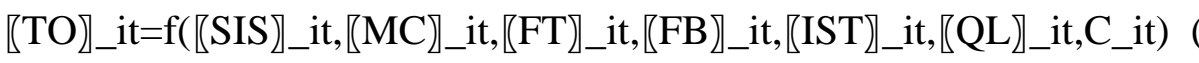

where at period $t$ and country i, TO refer to trade openness, SIS is secure internet servers (per 1 million people), MC is mobile cellular subscriptions (per 100 people), FT is fixed telephone subscriptions (per 100 people), FB is fixed broadband subscriptions (per 100 people), IST is interpersonal safety and trust, QL is quality of life, and C is a crime. We use the log form of the variables. Log transformation can lessen the violation of heteroscedasticity assumption because it compresses the scale of the measured variables. The new model is as follow:

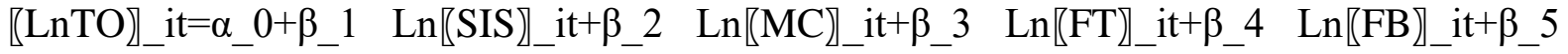

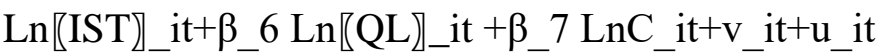

We allowed for the time and country effect as our model utilized the panel estimation technique. The fixed effect assumed constant error for each Asian country. The panel data estimation for $\mathrm{v}$ and $\mathrm{u}$ assumed that each country has its behaviour and is influenced by different factors represented by the slope and intercepts that is constant across countries and time.

One-Way Error Component Model

In one-way error component model, the composite error component does not include the unobservable time-specific effect $\lambda$ t. There are two kinds of model can be used in panel regression model:

Fixed Effect Model:

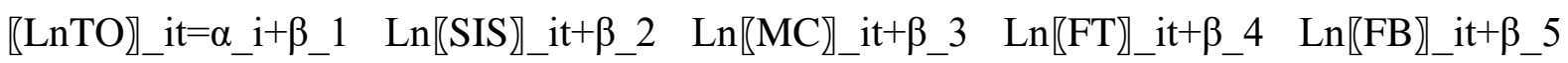
$\mathrm{Ln}$ [IST)_it $+\beta \_6 \mathrm{Ln} \llbracket \mathrm{QL} \rrbracket \_$it $+\beta \_7 \mathrm{LnC}$ it $+\mathrm{u}_{-}$it

where $u \_i t \sim N\left(0, \sigma \_u^{\wedge} 2\right)$. An individual intercept $\alpha \_i$ includes controlling for individualspecific and time-invariant characteristics. That intercepts are called fixed effects. Independent variables cannot be time-invariant. All time-invariant variables effect are represented by the intercept. Fixed effect captures the individual heterogeneity. The estimation methods of the fixed effect model are Least Square Dummy Variable (LSDV) estimator or the fixed effect estimator. It is not feasible to use the least square dummy variable estimator when $\mathrm{N}$ is large. 
International Journal of Innovation, Creativity and Change. www.ijicc.net

Volume 11, Issue 12, 2020

Random Effect Model:

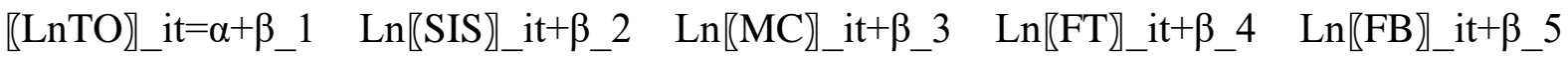
$\mathrm{Ln}\left[\mathrm{IST} \rrbracket \_i t+\beta \_6 \mathrm{Ln}\left[\mathrm{QL} \rrbracket \_i t+\beta \_7 \mathrm{LnC}\right.\right.$ it $+\mathrm{u}_{-}$it

The error component ( $u$ it) is the sum of the individual specific random component $\left(\mu \_i\right)$ and idiosyncratic disturbances $\left(\varepsilon \_\right.$it):

u_it $=\mu \_i+\varepsilon \_$it

Where $\mu \_$it $\sim \mathrm{N}\left(0, \sigma \_\mu^{\wedge} 2\right)$ and $\varepsilon \_$it $\sim \mathrm{N}\left(0, \sigma \_\varepsilon^{\wedge} 2\right)$. Independent variables can be time-invariant. Individual random effects are independent. The estimation methods of random effect model are generalized least square (GLS). This study uses Swamy-Arora method to estimate the random effect.

Two-Way Error Component Model

In two-way error component model, the composite error component includes the unobservable time-specific effect $\left(\lambda \_t\right)$, instead of the individual-specific effect. Same as oneway error component model, there are two kinds of models can be used in the panel regression model:

Fixed Effect Model:

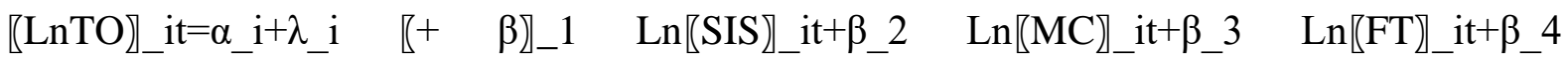
$\mathrm{Ln}\left[\mathrm{FB} \rrbracket \_\mathrm{it}+\beta \_5 \mathrm{Ln}(\mathrm{IST}) \_\mathrm{it}+\beta \_6 \mathrm{Ln}[\mathrm{QL}) \_\mathrm{it}+\beta \_7 \mathrm{LnC} \_\mathrm{it}+\mathrm{u} \_\mathrm{it}\right.$

where $u_{-} i t \sim N\left(0, \sigma_{-} u^{\wedge} 2\right)$. An individual intercept $\alpha \_i$ includes controlling for individualspecific and time-invariant characteristics. $\lambda_{-} \mathrm{i}$ is the time-specific intercept. Those intercepts are called fixed effects. Independent variables cannot be time-invariant. All time-invariant variables effect are represented by the intercept. Fixed effect captures the individual heterogeneity. The estimation methods of the fixed effect model are Least Square Dummy Variable (LSDV) estimator or the fixed effect estimator.

Random Effect Model:

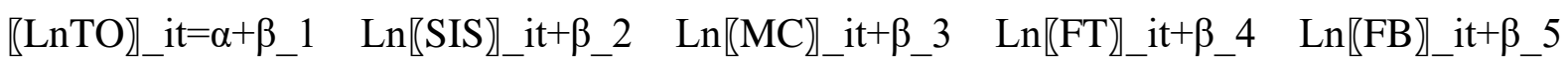
$\mathrm{Ln} \llbracket \mathrm{IST} \rrbracket \_i t+\beta \_6 \mathrm{Ln} \llbracket \mathrm{QL} \rrbracket \_i t+\beta \_7 \mathrm{LnC} \_\mathrm{it}+\mathrm{u}_{-}$it 
The error component ( $\left.u \_i t\right)$ is the sum of the individual-specific random component $\left(\mu \_i\right)$, time-specific random effect $\left(\lambda \_t\right)$ and idiosyncratic disturbances $\left(\varepsilon \_\right.$it):

$u_{-}$it $=\mu \_$i $+\lambda \_t+\varepsilon$ it

Where $\mu \_$it $\sim \mathrm{N}\left(0, \sigma \_\mu^{\wedge} 2\right), \lambda \_\mathrm{t} \sim \mathrm{N}\left(0, \sigma \_\lambda^{\wedge} 2\right)$, and $\varepsilon \_$it $\sim \mathrm{N}\left(0, \sigma \_\varepsilon^{\wedge} 2\right)$. Independent variables can be time-invariant. Individual random effects are independent. The estimation methods of random effect model are generalized least square (GLS). This study uses Swamy-Arora method to estimate the random effect.

\section{Results and Findings}

\section{Overview of Trade Openness, Social, and Security Indicators among Asian Countries}

This study used data from 17 countries in Asian from 2010 to 2018. Based on Figure 6, it can be seen that the Trade Openness (\%) in Asia, the highest is Hong Kong, followed by Singapore. Hong Kong has an average trade openness during the period 2010 to 2017 of 461 per cent. This shows that the number of exports and imports of Hongkong is about four times its GDP. Pakistan has the lowest trade openness, with only 33 per cent trade openness. This shows that the amount of exports and imports is only one-third of its GDP. This is allegedly because Pakistan still enforces closed economy. 
International Journal of Innovation, Creativity and Change. www.ijicc.net Volume 11, Issue 12, 2020

Figure 6. Trade Openness (\%) of Asian Countries, 2010 - 2017

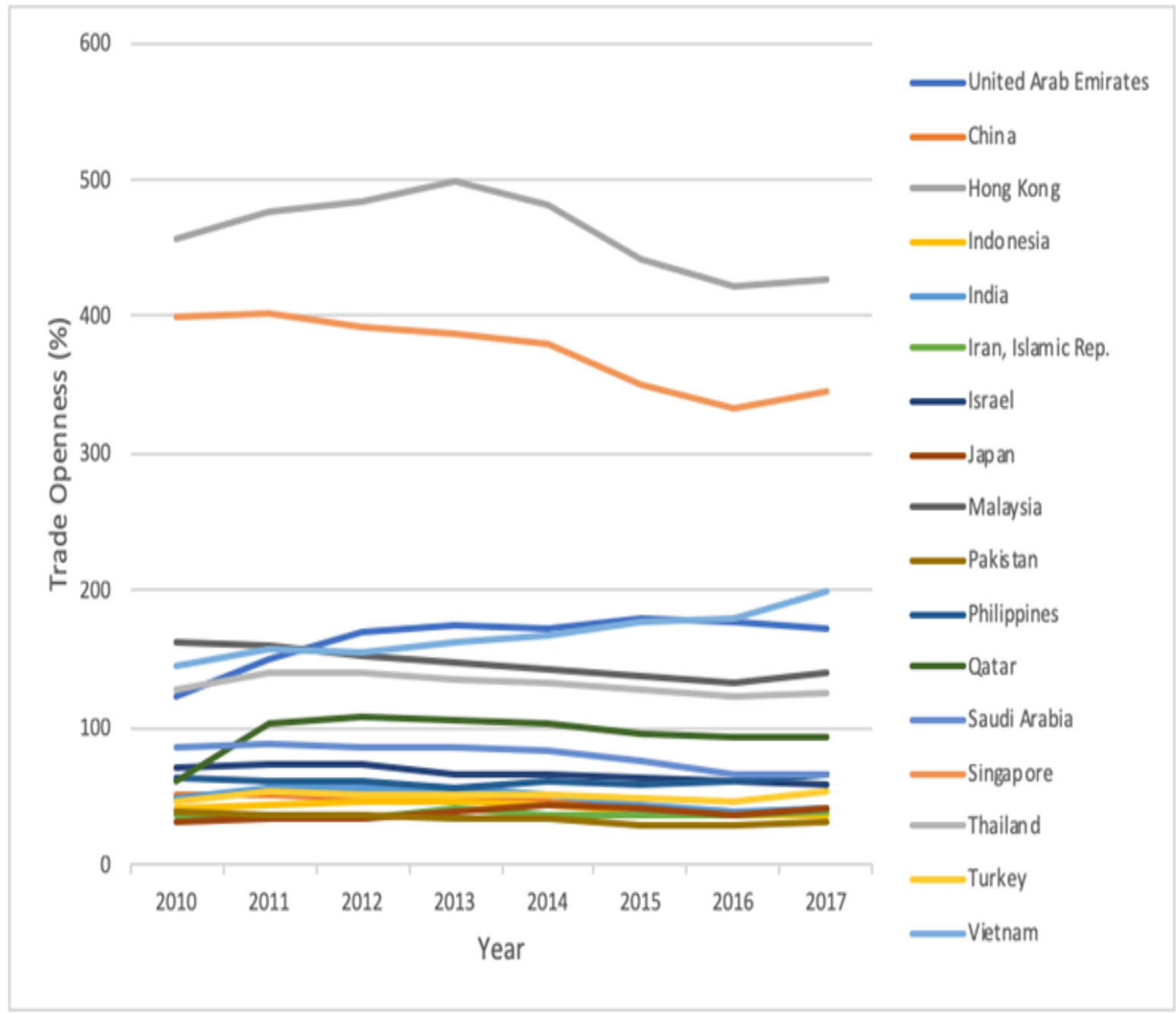

Source: World Bank (2010-2017), processed

In Figure 6, it can be seen that Hong Kong and Singapore experienced very high trade openness, leaving other Asian countries. If Hongkong and Singapore are excluded, it will look like the picture below (Figure 7): 
International Journal of Innovation, Creativity and Change. www.ijicc.net Volume 11, Issue 12, 2020

Figure 7. Trade Openness (\%) of Asian Countries, 2010 - 2017, exclude Hongkong and Singapore

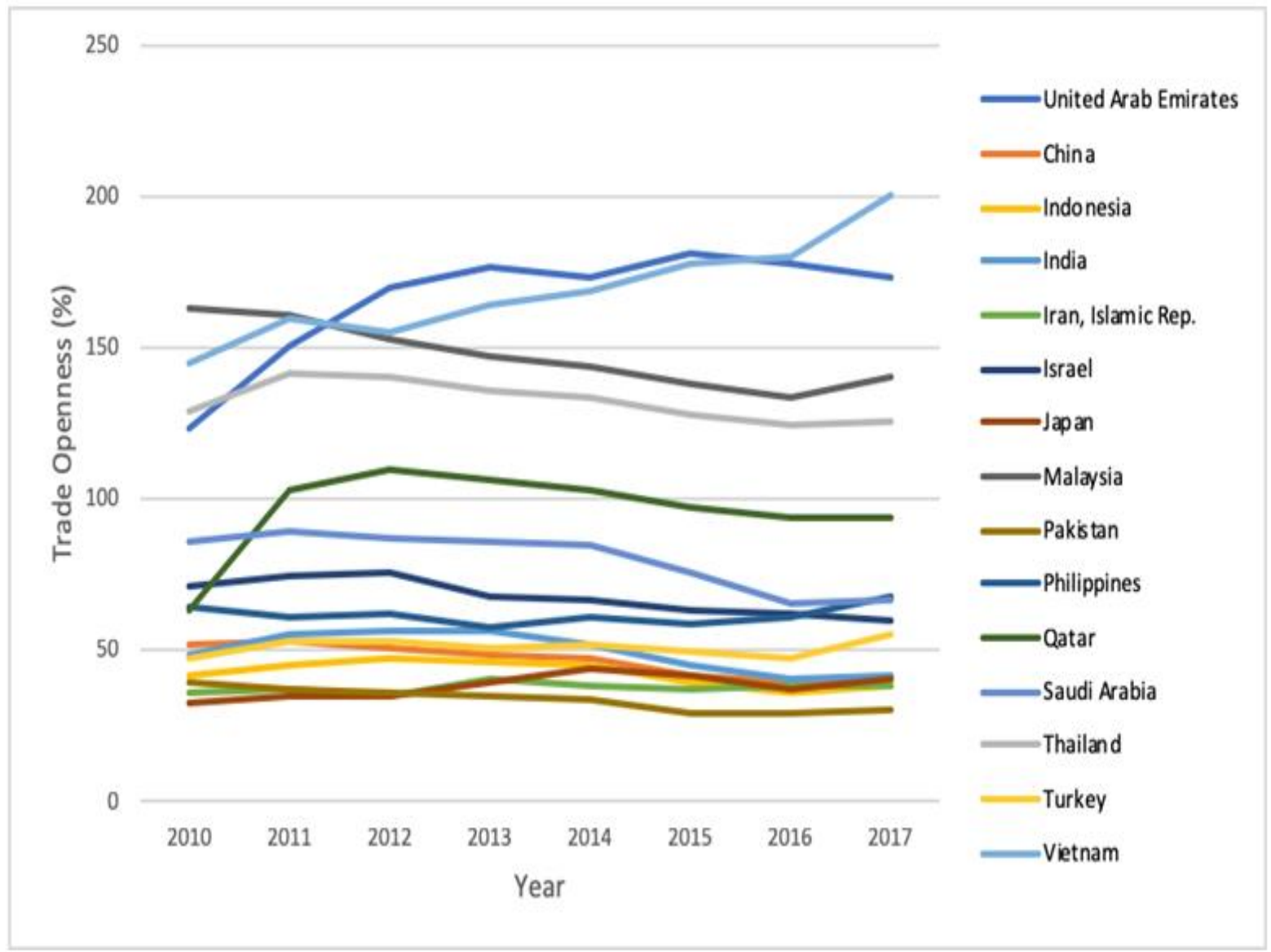

Source: World Bank (2010-2017), processed

From Figure 7 it can be seen that the high trade openness is in Vietnam, the United Arab Emirates, Malaysia and Thailand. So far, China's trade openness value is still at the bottom value, allegedly because the value of China's GDP is very high compared to its trade value (exports plus imports).

High potential in Asian countries in engages trade openness is also supported by changes in institutional and start-up policy/ procedures. This can be seen in Table 1. 
International Journal of Innovation, Creativity and Change. www.ijicc.net

Volume 11, Issue 12, 2020

Table 1: Policy Indicators to Start-Up Business in Asian Countries

\begin{tabular}{|c|c|c|c|c|c|c|c|}
\hline \multirow[t]{2}{*}{ No } & \multirow[t]{2}{*}{$\begin{array}{l}\text { Country } \\
\text { Name }\end{array}$} & \multicolumn{2}{|c|}{$\begin{array}{l}\text { Start-up } \\
\text { procedures to } \\
\text { register a } \\
\text { business } \\
\text { (number) }\end{array}$} & \multicolumn{2}{|c|}{$\begin{array}{c}\text { Time required to } \\
\text { enforce a contract } \\
\text { (days) }\end{array}$} & \multicolumn{2}{|c|}{$\begin{array}{c}\text { Time required to } \\
\text { start a business } \\
\text { (days) }\end{array}$} \\
\hline & & 2013 & 2017 & 2013 & 2017 & 2013 & 2017 \\
\hline 1 & $\begin{array}{l}\text { United Arab } \\
\text { Emirates }\end{array}$ & 6 & 4 & 524 & 445 & 8.2 & 8.2 \\
\hline 2 & China & 11 & 7 & 496.3 & 496.3 & 32.4 & 22.9 \\
\hline 3 & Hong Kong & 3 & 2 & 385 & 385 & 2.5 & 1.5 \\
\hline 4 & Indonesia & 11 & 11 & 471 & 403.3 & 75.5 & 23.1 \\
\hline 5 & India & 13 & 11 & 1445 & 1445 & 32.6 & 29.8 \\
\hline 6 & $\begin{array}{l}\text { Iran, Islamic } \\
\text { Rep. }\end{array}$ & 10 & 9 & 505 & 505 & 18.5 & 15 \\
\hline 7 & Israel & 5 & 4 & 975 & 975 & 13 & 12 \\
\hline 8 & Japan & 9 & 9 & 360 & 360 & 12.7 & 12.2 \\
\hline 9 & Malaysia & 6 & 8 & 425 & 425 & 9.5 & 18.5 \\
\hline 10 & Pakistan & 12 & 12 & 1071.2 & 1071.2 & 19 & 17.5 \\
\hline 11 & Philippines & 16 & 16 & 962 & 962 & 36 & 28 \\
\hline 12 & Qatar & 8 & 8 & 570 & 570 & 8.7 & 8.7 \\
\hline 13 & $\begin{array}{l}\text { Saudi } \\
\text { Arabia }\end{array}$ & 14 & 11 & 635 & 575 & 24.8 & 17.8 \\
\hline 14 & Singapore & 3 & 3 & 164 & 164 & 2.5 & 2.5 \\
\hline 15 & Thailand & 7 & 5 & 440 & 420 & 29.5 & 4.5 \\
\hline 16 & Turkey & 7 & 7 & 420 & 580 & 7 & 6.5 \\
\hline 17 & Vietnam & 9 & 9 & 400 & 400 & 34 & 22 \\
\hline
\end{tabular}

Source: WDI, 2017

Asian developing countries have recently practised intensive trade liberalization policies to increase growth. Based on Table 1 it can be seen that there is an acceleration in the process of registering and starting a business or time to enforce a contract. , The rapid growth of ecommerce and online shops, is supported in terms of uncomplicated regulations and procedures.

It is seen that Indonesia, the time required to start a business in 2013 is 75,5 days to be shorter, namely 23,1 days in 2017. Similarly, in Thailand, the time needed to start a business dropped dramatically from 29.5 days to only 4,5 days in 2017. In the past two decades, 
International Journal of Innovation, Creativity and Change. www.ijicc.net Volume 11, Issue 12, 2020

Thailand is one of these economies that achieve miracle. (Wattanakul, 2010) concluded that Thailand's openness with its seven major trade partners: ASEAN4 (Indonesia, Malaysia, Philippines, and Singapore), Australia, the US, the EU, China, Japan and India) is growing fast in the past two decades because of massive policy reformations.

Apart from the policy side that supports, internet penetration in Asia is currently at 48\%, and should reach $59 \%$ by 2021 . The penetration of the smartphone was $35 \%$, and it is expected to reach $44 \%$ by 2021 . In addition, $48 \%$ of online shoppers in Asia prefer to shop online via desktop, which is lower than the global average, $19 \%$ of online shoppers use mobile, and $25 \%$ claim to have no preference (Statista, 2017). Figure 8 shows that there is a drastic increase in the secure internet servers in Asian countries in 2016 and 2017. Hong Kong still dominates secure internet servers in Asian countries. Secure internet servers are growing very fast after 2015 as an impact of digitalization in Asia.

Figure 8. Secure Internet Servers (per 1 million people) in Asian countries, 2010 - 2017

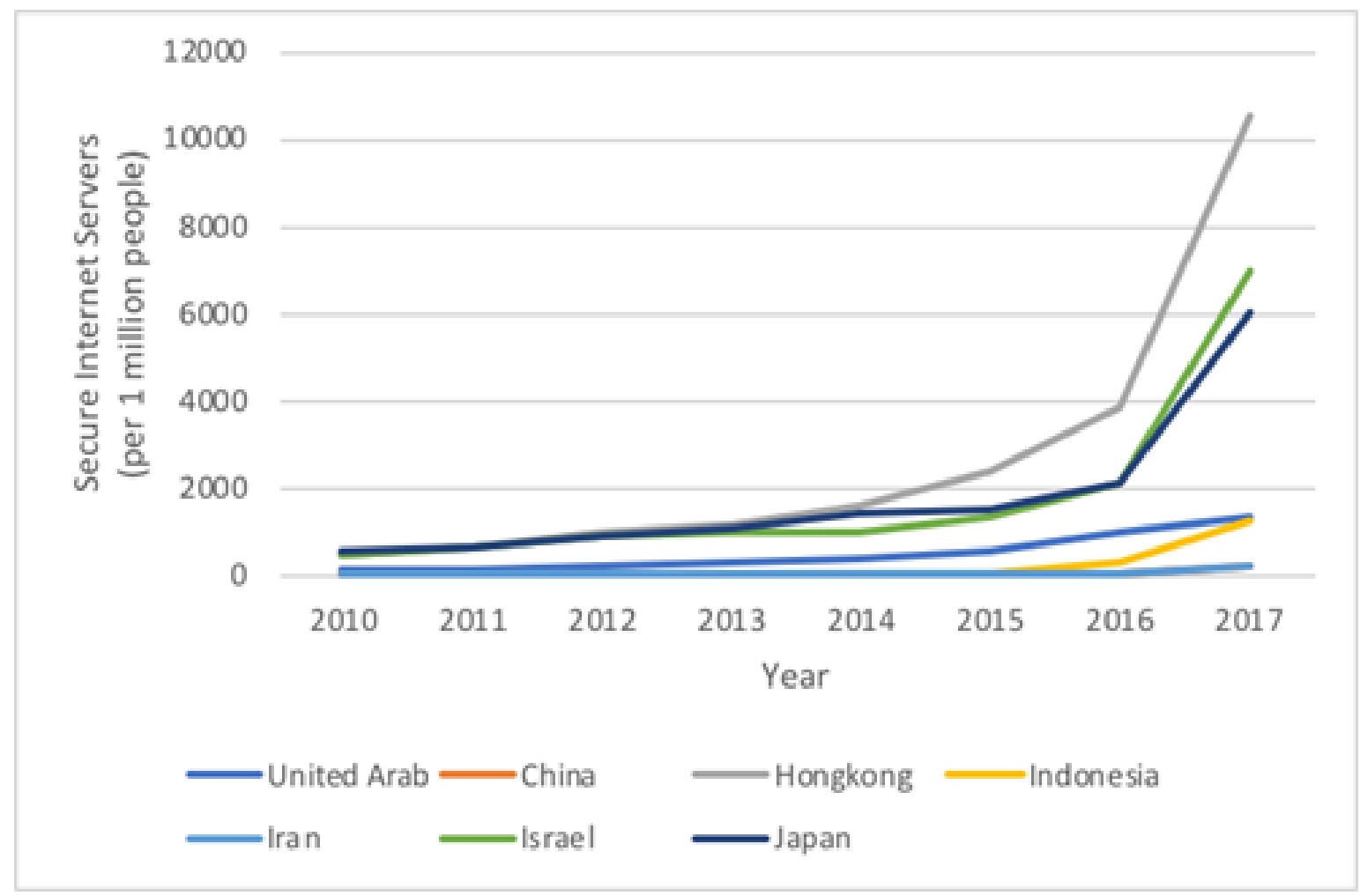

Figure 9 shows the mobile cellular subscriptions in Asian countries. The highest was in Hong Kong, which was followed by the United Arab Emirates. It is seen that there is a slight increasing trend from 2010 to 2017. In Asian countries, mobile cellular subscriptions are quite high, with average estimates of 126.29 per 100 people. It means that the average 
International Journal of Innovation, Creativity and Change. www.ijicc.net Volume 11, Issue 12, 2020

number of mobile cellular use in Asia has exceeded its population. The country experienced the lowest mobile cellular subscription is Pakistan, that only 67.17 per 100 people.

Figure 9. Mobile Cellular Subscriptions (per 100 people) in Asian countries, 2010 - 2017

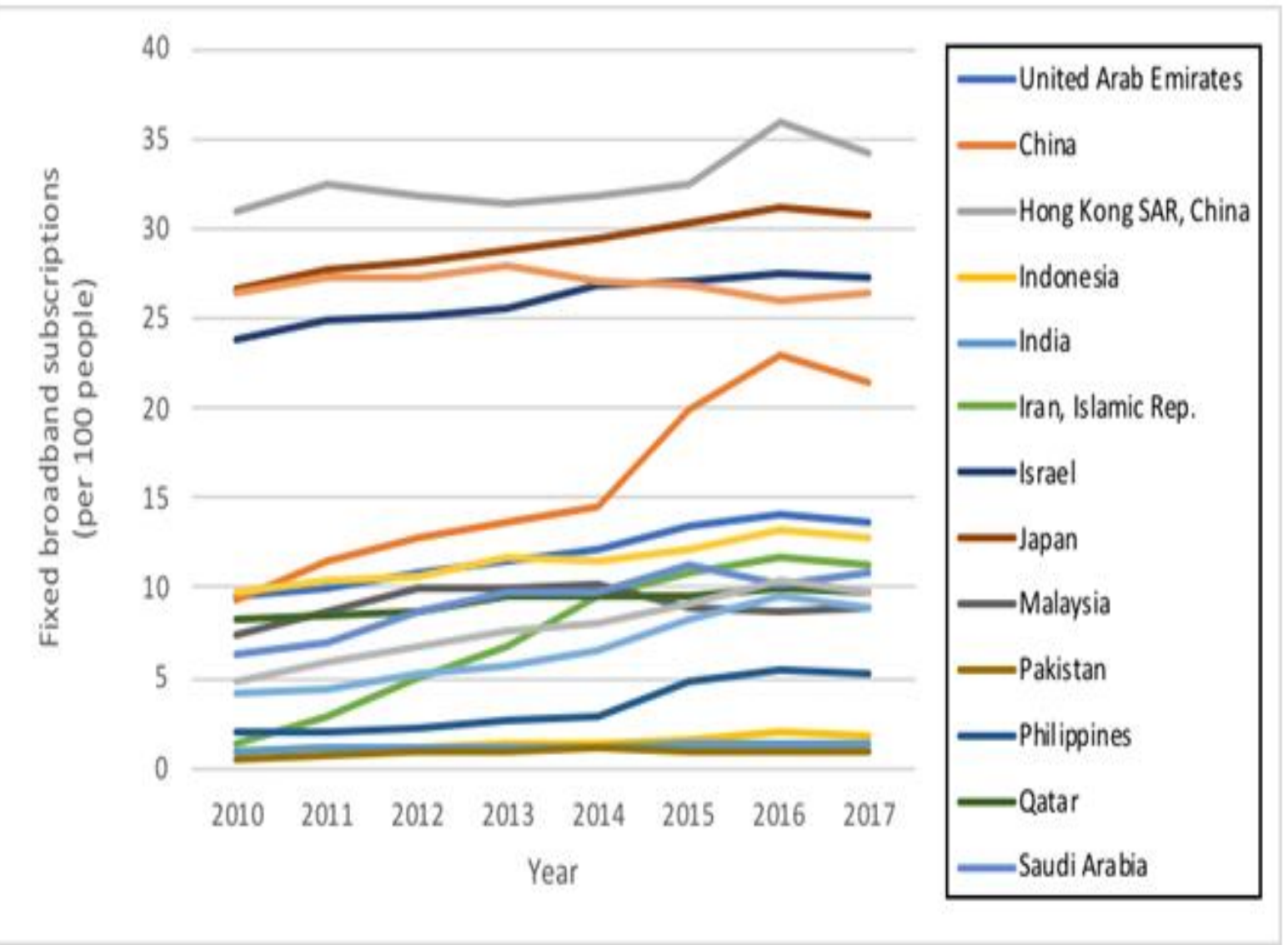

Source: ITU (2010-2017), processed

Asia is arguably the most diverse region in the world in terms of the telecommunications industry. This region contains a large number of countries, ranging from countries with a very mature and advanced telecommunications market, which are world leaders in the movement towards 5G and next-generation fibre networks, such as South Korea, Hong Kong, Singapore and Japan, to several countries. The poorest and least developed such as North Korea and Afghanistan. The fixed broadband market throughout Asia continues to experience very strong growth. The government is strengthening the development of fixed broadband through sharing passive infrastructure, promoting open access, and developing multi-mode solutions that include fibre, wireless spectrum, and satellite.

Quality of Life index is one of social indicator that reflects economic well-being. Wellbeing societies/countries have more significant opportunities to engage in trade openness. 
International Journal of Innovation, Creativity and Change. www.ijicc.net Volume 11, Issue 12, 2020

Figure 10. Trade Openness and Quality of Life Among Asian Countries, 2017

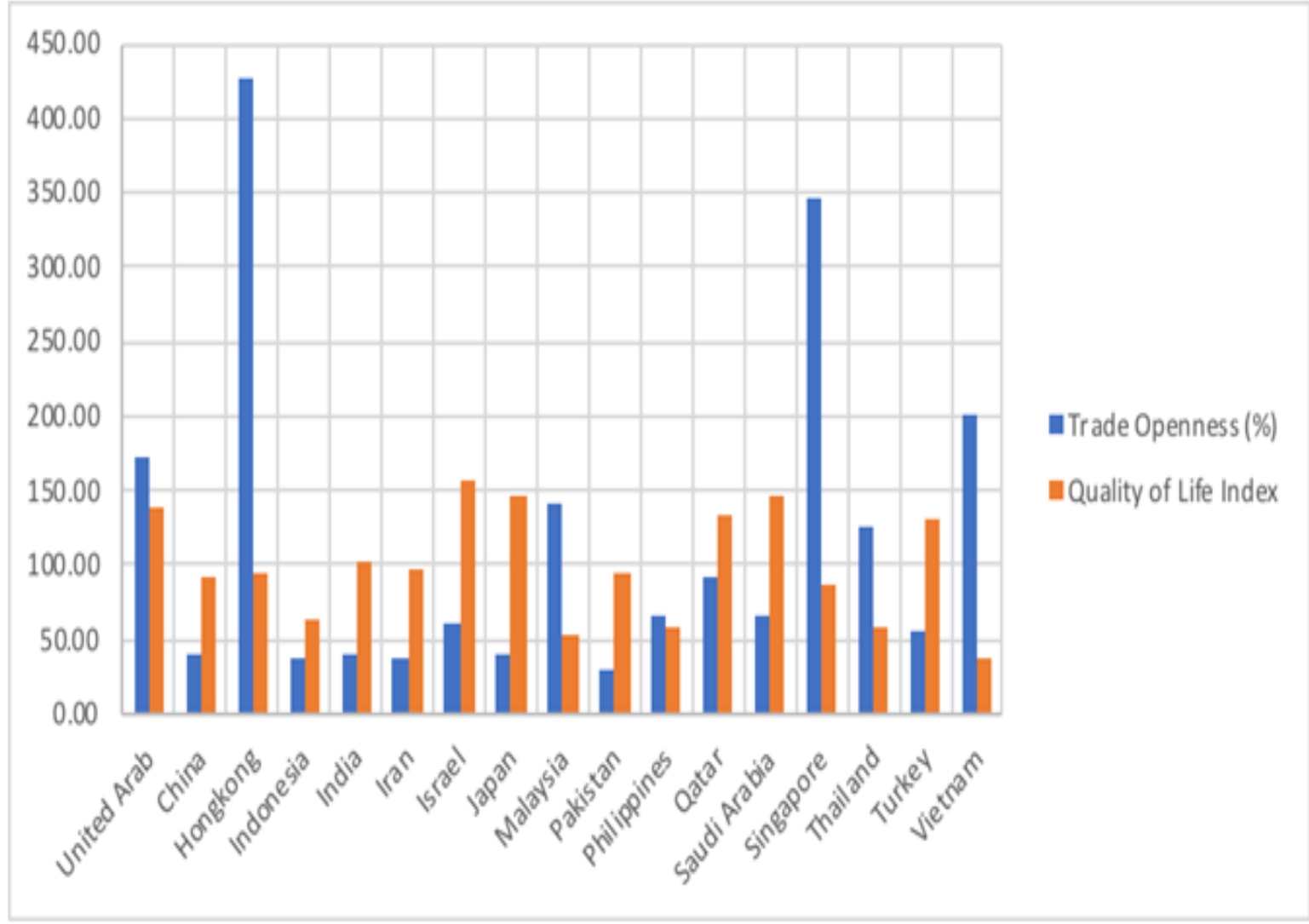

Source: World Bank, Numbeo (2017), processed

Figure 10 shows that a high trade openness does not necessarily follow high quality of life. This can be seen in Israel, Japan, Qatar, Saudi Arabia, and Turkey, where it has a relatively high quality of life index but low trade openness. 
International Journal of Innovation, Creativity and Change. www.ijicc.net Volume 11, Issue 12, 2020

Figure 11. Trade Openness and Crime Index Among Asian Countries, 2017

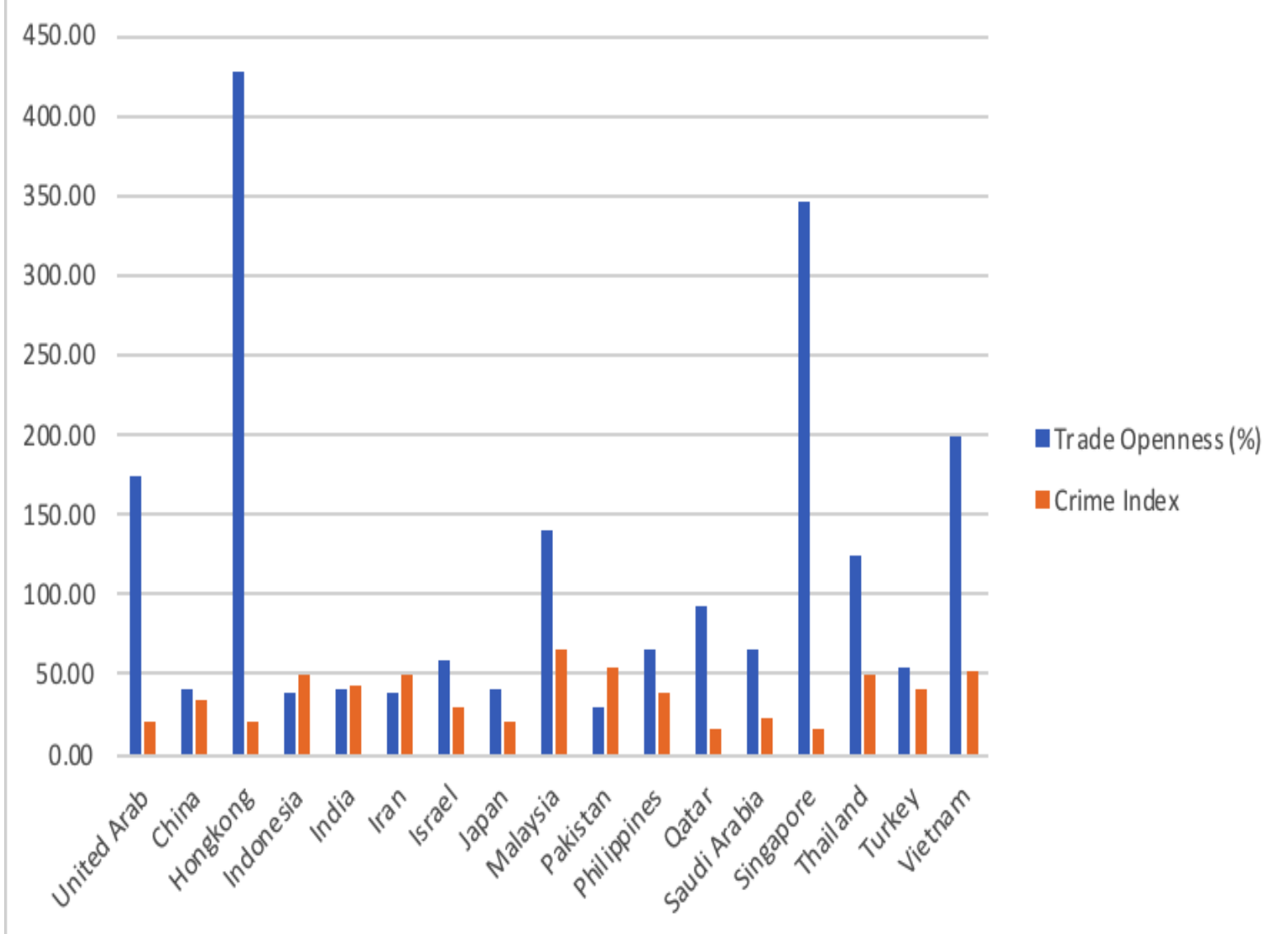

Source: World Bank, Numbeo (2017), processed

Figure 11 shows that in countries with high trade openness such as Hong Kong, Singapore and the UAE, they have a relatively low crime index. These countries are developed countries in Asia so that the majority of the people have prospered. High welfare will reduce crime rates. 
International Journal of Innovation, Creativity and Change. www.ijicc.net Volume 11, Issue 12, 2020

Figure 12. Interpersonal Safety and Trust Index Among Asian Countries, 2012 - 2017

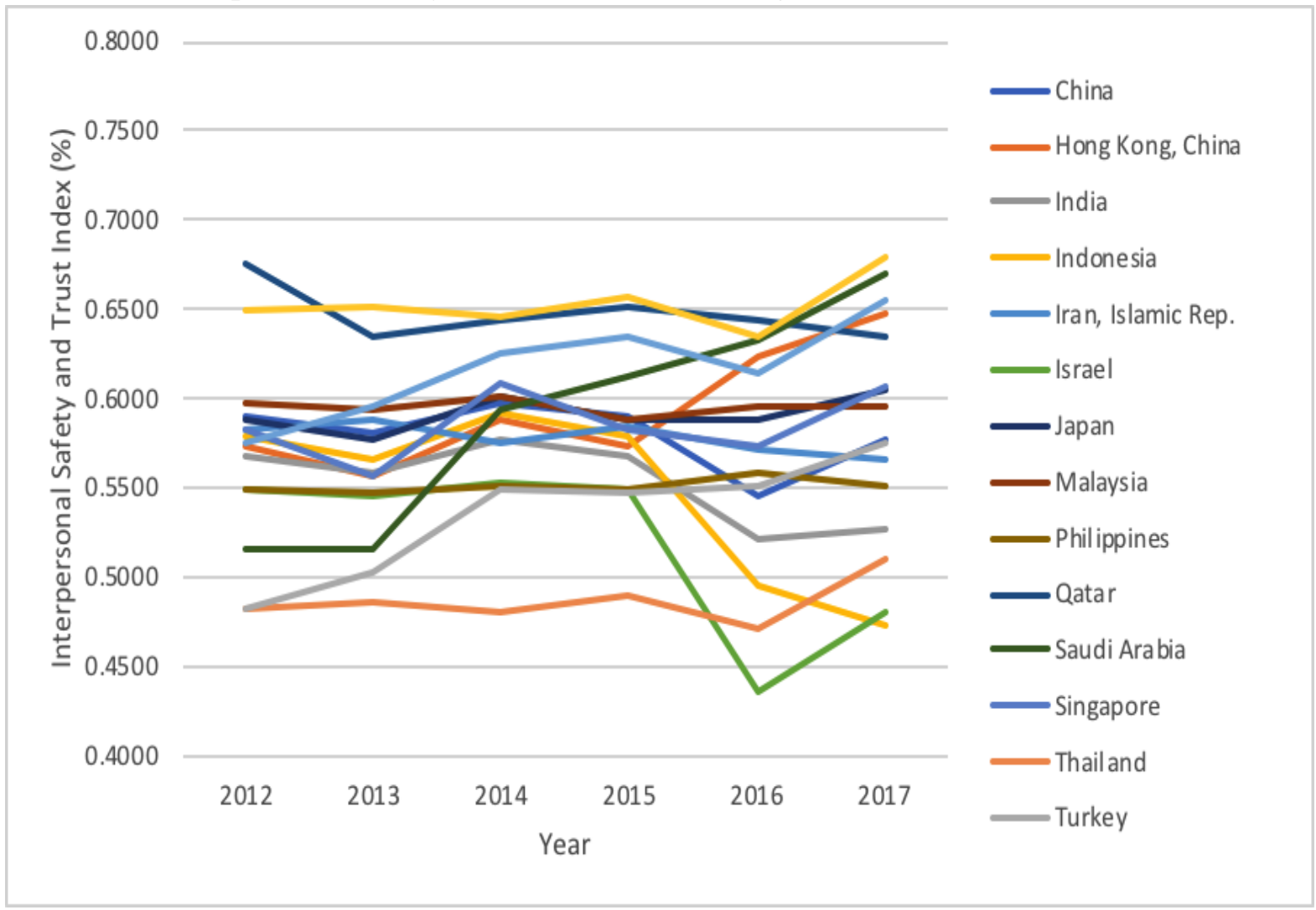

Source: Indices of Social Development (2012-2017), processed

Need further study of interpersonal safety and trust index, considering that in 2015 there was a Terror Attack in Paris which ISIS has claimed responsibility and Refugee Crisis where tens of thousands of people fleeing war-torn Syria (Syria) and other areas in the Middle East and Africa. This is suspected to be the cause of the decline in interpersonal safety and trust index in 2015.

\section{Panel Regression Analysis}

Panel data analysis has become more popular among researcher. Panel data sets provide multiple advantages over cross-section (individual) and time-series data set. Panel data analysis is used to estimate the impact of ICT indicators (secure internet servers, fixed telephone subscriptions, fixed broadband subscriptions, and mobile-cellular subscriptions) and social indicators (interpersonal safety and trust index, quality of life index, and crime index) on trade openness in the Asian region. In this paper, we begin several diagnostics. In order to determine the better model between pooled (OLS) and panel fixed effect model, we use test of poolability. In order to determine the better model between pooled (OLS) and panel random effect model, we use Lagrange Multiplier Test - (Breusch-Pagan) for a random 
International Journal of Innovation, Creativity and Change. www.ijicc.net Volume 11, Issue 12, 2020

effect. We also run $\mathrm{F}$ test for individual and time effects of testing whether no individual effect across countries and no time effect, respectively. Furthermore, in order to determine the type of our model, we use Hausman test. The Hausman test is a test of the significance of the difference between the fixed effects estimates and the random effects estimates. Once we get the preferred form of the model, we made a brief analysis based on the result that we derive from the GLS estimation. Table 2 gives a summary of diagnostics.

Table 2: Diagnostics of Panel Regression

\begin{tabular}{|c|c|c|c|}
\hline Diagnostics & Null Hypothesis & Results & Conclusion \\
\hline Tests of poolability & $\begin{array}{l}\text { Pooled model (OLS) } \\
\text { better than fixed effect } \\
\text { (within) model }\end{array}$ & $\mathrm{p}$-value $<2.2 \mathrm{e}-16$ & $\begin{array}{l}\text { Fixed effect } \\
\text { performs better } \\
\text { than OLS }\end{array}$ \\
\hline $\begin{array}{l}\text { Lagrange Multiplier } \\
\text { Test - (Breusch-Pagan) } \\
\text { for random effect }\end{array}$ & $\begin{array}{l}\text { No panel effect; Pooled } \\
\text { model (OLS) better } \\
\text { than random effect } \\
\text { model }\end{array}$ & p-value $<2.2 \mathrm{e}-16$ & $\begin{array}{l}\text { Random effect } \\
\text { performs better } \\
\text { than OLS }\end{array}$ \\
\hline $\begin{array}{l}\text { F test for individual } \\
\text { effects }\end{array}$ & $\begin{array}{l}\text { No individual effect } \\
\text { (One-way time effects } \\
\text { error component) }\end{array}$ & $\mathrm{p}$-value $<2.2 \mathrm{e}-16$ & $\begin{array}{l}\text { There are } \\
\text { individual } \\
\text { effects }\end{array}$ \\
\hline$F$ test for time effects & $\begin{array}{l}\text { No time-effect } \\
\text { (One-way individual } \\
\text { effects error } \\
\text { component) }\end{array}$ & $\begin{array}{l}\mathrm{p} \text {-value }= \\
0.0006252\end{array}$ & $\begin{array}{l}\text { There are time } \\
\text { effects }\end{array}$ \\
\hline $\begin{array}{l}\text { Lagrange Multiplier } \\
\text { Test - two-ways effects } \\
\text { (Gourieroux, Holly and } \\
\text { Monfort) for balanced } \\
\text { panels }\end{array}$ & $\begin{array}{l}\text { No individual and time } \\
\text { effect }\end{array}$ & p-value $<2.2 \mathrm{e}-16$ & $\begin{array}{l}\text { Two-ways } \\
\text { effect model } \\
\text { (individual and } \\
\text { time effects) }\end{array}$ \\
\hline Hausman Test & $\begin{array}{l}\text { Preferred model is } \\
\text { random effects vs. the } \\
\text { alternative the fixed } \\
\text { effects }\end{array}$ & $\mathrm{p}$-value $=0.3065$ & $\begin{array}{l}\text { Random Effect } \\
\text { performs better } \\
\text { than fixed effect }\end{array}$ \\
\hline $\begin{array}{l}\text { Breusch-Pagan } \\
\text { Heteroscedasticity Test } \\
\text { of Random Effect }\end{array}$ & Homoscedastic & $\mathrm{p}$-value $=0.007941$ & Heteroscedastic \\
\hline
\end{tabular}

With regards to the diagnostic results, our analysis finds that the utilization of panel data is well suited for this data. The model estimation results for this panel regression analysis is shown in Table 3. This analysis uses GLS instead of OLS. Next, we had used the Hausman 
International Journal of Innovation, Creativity and Change. www.ijicc.net Volume 11, Issue 12, 2020

test on the random effect regression to determine the best model between the random and fixed effect regressions. Based on Table 2, the preferred model is a random effect given that the p-value of 0.3065 suggests to not reject the null hypothesis. The $\mathrm{F}$ test for individual effects and time effects concludes that the best model is two-ways effect model. So, the preferred model is two ways (individual and time) - random effect model. Then, we run Breusch-Pagan Heteroscedasticity Test of Random Effect; the null hypothesis is rejected so we use robust covariance matrix estimation. We can conclude that only country-specific random effects influence trade openness in Asia countries.

Table 3: Panel Regression Results

\begin{tabular}{|c|c|c|}
\hline \multirow{2}{*}{ Variables } & \multicolumn{2}{|l|}{ Random Effect } \\
\hline & Estimate & Standard Error \\
\hline Intercept & $3.6696206^{\mathrm{a}}$ & 0.5886435 \\
\hline LnSecureInternetServers & 0.0081091 & 0.0131002 \\
\hline LnMobileCellular & -0.1128880 & 0.1289273 \\
\hline LnFixedTelp & $0.2173021^{\mathrm{a}}$ & 0.0431792 \\
\hline LnFixedBroadband & $0.1333168^{\mathrm{b}}$ & 0.0552733 \\
\hline LnInterpersonalSafetyTrust & 0.0368916 & 0.1373826 \\
\hline LnQualityLife & 0.0099028 & 0.0089882 \\
\hline LnCrime & $0.1132251^{\mathrm{a}}$ & 0.0359916 \\
\hline $\mathbf{R}^{2}$ & 0.3137 & - \\
\hline Adjusted R $\mathbf{R}^{2}$ & 0.2626 & - \\
\hline F or Chisq. Statistics & $42.9672^{\mathrm{a}}$ & - \\
\hline
\end{tabular}

Balanced Panel: $\mathrm{n}=17, \mathrm{~T}=6, \mathrm{~N}=102$

${ }^{a}$ Denotes significance level for $1 \%$ level

${ }^{b}$ Denotes significance level for $5 \%$ level

Based on Table 3, of the 7 independent variables used there are 3 variables that have a significant impact on trade openness in 17 Asian countries, namely: fixed telephone subscriptions (per 100 people), fixed broadband subscriptions (per 100 people), and crime. Secure internet server (per 1 million people) have a positive sign to trade openness when it increases by 1 per cent, then trade openness will increase by 0.0081 per cent. This is possible because the impact of the increase in secure internet server is on increasing e-trade (export and import) remains, in the end, it will increase trade openness. However, the impact is not statistically significant.

Mobile cellular subscriptions (per 100 people) have a negative relationship with trade openness, but statistically insignificant. Although, theoretically mobile cellular subscriptions as one of the forms of internet openness could have positive effects on international trade 
International Journal of Innovation, Creativity and Change. www.ijicc.net Volume 11, Issue 12, 2020

openness. At the basic level, transparency facilitates trade by making it easier for suppliers to connect with customers in other countries, increasing logistical control, and making it possible to complete transactions and deliver products or services more efficiently. Internet openness also plays an essential role in oiling the global value chain. At present most of the trade is semi-finished goods and services, with inputs sourced globally and stages of production shifting from one place to another., The openness of the internet, enhances the ability of companies of all sizes and nationalities to find a niche in global trade by enabling them to coordinate their participation. Because seamless data transfer across national borders is an important part of how global value chains operate, small friction can breed into significant obstacles. Numerous studies have expressed concern that overly strict data regulation can hamper trade, which in turn results in greater production inefficiencies at the global level. Costs tend to fall more heavily on smaller companies that have less capacity to duplicate data management systems across countries and navigate complex regulatory requirements. This can also have a negative impact on development and trade openness in developing countries if services such as finance grow more slowly. Emerging markets Asia countries consist of 9 countries: China, India, Indonesia, Korea, Malaysia, Pakistan, Philippines, Taiwan and Thailand. Seven of the nine emerging Asian economies are included in this study.

Fixed telephone subscriptions and fixed broadband subscription have a positive and significant impact on trade openness. This is alleged because, in 17 Asian countries which are dominated by emerging countries, the use of fixed telephone and fixed broadband is still the main focus, for example, Indonesia. Based on UNESCAP Working Paper 2016, Indonesia's medium-term national development plan for ICT, covering the period from 2015 to 2019, aims to strengthen fixed broadband development through the sharing of passive infrastructure, the promotion of open access, and the development of multi-mode solutions that include fibre, wireless spectrum, and satellite (UNESCAP, 2016). A five-year broadband plan ranging from 2014 to 2019 has been adopted by Indonesia, known as the Indonesia Broadband Plan (IBP), which focuses on "innovation" to enable penetration, adoption and effective use of broadband services to all districts, schools and facilities other public, as well as the government. In 2019, for urban areas, IBP called for a fixed broadband penetration rate of 71 per cent from households and a cellular broadband penetration of 100 per cent, while urban areas will each have fixed broadband penetration rates of 49 per cent and 52 per cent, respectively. Fixed broadband speeds in urban areas will be $20 \mathrm{Mbps}$ and $10 \mathrm{Mbps}$ in rural areas, while cellular broadband speeds will be at least $1 \mathrm{Mbps}$.

Interpersonal safety and trust, as well as the quality of life aspects, have a positive sign. However, both of these variables are statistically not significant. In other words, theoretically, 
International Journal of Innovation, Creativity and Change. www.ijicc.net Volume 11, Issue 12, 2020

an increase in interpersonal safety and trust as well as the quality of life leads to rises on trade openness, but the data used in this study did not support these hypotheses.

Crime has significant impact to trade openness. This results in line with the research of (J. E. Anderson \& Marcouiller, 2002). However, the relationship is positive. It means, crime increases then trade openness increases, vice versa. Theoretically, crime has an impending negative effect on human and capital stock, which are the crucial economic determinants, because it decreases both the tangible and intangible welfare of individuals and of the societies as a whole (D. A. Anderson, 1999; McCollister et al., 2010). In Asia, governments concern of their human and capital stock before engaging in trade such as seeking for countries where their trading agents would be relatively safe. In addition, socio-cultural factors are deeply rooted into a nation's culture, therefore crime might be a consequence of a culture and less the other way around. Geographic location and demographic trend might also affect crime due to migration, age distribution, and population density. The majority of Asian countries are still attached to their cultural values, so we need further research to see the effect of crime on trade openness more deeply.

This study finds and confirms that ICT, social and security indicators play an important role in improving the trade openness. Therefore, it is prominent for the leaders of Asia countries to learn and adapt the knowledge of ICT, social and security indicators, especially in emerging Asia countries.

\section{Conclusions}

Asian countries experience acceleration in engage trade openness, seen from several regulations/procedural indicators such as reduced start-up procedures to register a business, reduced time required to enforce a contract, and time required to start a business faster from 2013 to 2017. Asian countries experienced rapid trade openness growth since 2016, dominated by Hongkong and Singapore. Of the 7 independent variables used 3 variables have a significant impact on trade openness in 17 Asian countries, namely: fixed telephone subscriptions (per 100 people), fixed broadband subscriptions (per 100 people), and crime. Fixed telephone subscriptions and fixed broadband subscription have a positive and significant impact on trade openness. This is alleged because, in 17 Asian countries which are dominated by emerging countries, the use of fixed telephone and fixed broadband is the main focus. The governments strengthen fixed broadband development through the sharing of passive infrastructure, the promotion of open access, and the development of multi-mode solutions that include fibre, wireless spectrum, and satellite. Crime has significant impact on trading openness in a positive relationship. In Asia, governments concern of their human and capital stock before engaging in trade such as seeking for countries where their trading agents 
would be relatively safe. In addition, socio-cultural factors are deeply rooted in a nation's culture; therefore crime might be a consequence of culture and less the other way around. Geographic location and demographic trends might also affect crime due to migration, age distribution, and population density. The majority of Asian countries are still attached to their cultural values, so we need further research to see the effect of crime on trade openness more deeply. Interpersonal safety and trust, as well as the quality of life indicator, have a positive sign; however, both of these variables are statistically not significant.

\section{Acknowledgement}

The authors gratefully acknowledge the use of the services, facilities, and funding from the Politeknik Statistika STIS. 
International Journal of Innovation, Creativity and Change. www.ijicc.net

Volume 11, Issue 12, 2020

\section{REFERENCES}

Adekoya, A. F., \& Razak, N. A. A. (2017). The dynamic relationship between crime and economic growth in Nigeria. International Journal of Management and Economics, 53(1), 47-64.

Algan, Y., \& Cahuc, P. (2010). Inherited trust and growth. American Economic Review, 100(5), 2060-2092.

Anderson, D. A. (1999). The aggregate burden of crime. The Journal of Law and Economics, 42(2), 611-642.

Anderson, J. E., \& Marcouiller, D. (2002). Insecurity and the pattern of trade: An empirical investigation. Review of Economics and statistics, 84(2), 342-352.

Arrow, K. J. (1972). Gifts and exchanges. Philosophy \& Public Affairs, 343-362.

Burnham, R., Feinberg, R. M., \& Husted, T. A. (2004). Central city crime and suburban economic growth. Applied Economics, 36(9), 917-922.

Cárdenas, M. (2001). Economic growth in Colombia: a reversal of'fortune'? CID Working Paper Series.

Chatterjee, I., \& Ray, R. (2009). Crime, corruption and institutions. Monash University, Department of Economics Discussion Paper, 20(09).

Daniele, V., \& Marani, U. (2011). Organized crime, the quality of local institutions and FDI in Italy: A panel data analysis. European Journal of Political Economy, 27(1), 132-142.

Dollar, D., \& Kraay, A. (2004). Trade, growth, and poverty. The Economic Journal, 114(493), F22-F49.

Erikson, R. (1993). Descriptions of Inequality: The Swedish Approach to Welfare Research145. The quality of life, 67.

Erikson, R., Hansen, E. J., Uusitalo, H., \& Ringen, S. (1987). The Scandinavian model: Welfare states and welfare research: ME Sharpe.

Gaibulloev, K., \& Sandler, T. (2008). Growth consequences of terrorism in Western Europe. Kyklos, 61(3), 411-424. 
International Journal of Innovation, Creativity and Change. www.ijicc.net Volume 11, Issue 12, 2020

Goulas, E., \& Zervoyianni, A. (2013). Economic growth and crime: does uncertainty matter? Applied Economics Letters, 20(5), 420-427.

Guiso, L., Sapienza, P., \& Zingales, L. (2006). Does culture affect economic outcomes? Journal of Economic perspectives, 20(2), 23-48.

Hall, P. (1995). Towards a general urban theory: Cities in competition. In: Melbourne, Australia: Longman.

Lambiri, D., Biagi, B., \& Royuela, V. (2007). Quality of life in the economic and urban economic literature. Social Indicators Research, 84(1), 1.

Mauro, L., \& Carmeci, G. (2007). A poverty trap of crime and unemployment. Review of Development Economics, 11(3), 450-462.

McCollister, K. E., French, M. T., \& Fang, H. (2010). The cost of crime to society: New crime-specific estimates for policy and program evaluation. Drug and alcohol dependence, 108(1-2), 98-109.

Nath, H. K., \& Liu, L. (2012). Information and Communications Technology (ICT) and Trade in Emerging Market Economies. Retrieved from

Numbeo. (2017). Retrieved from https://www.numbeo.com/quality-of-life/

OECD. (2019). Why open markets matter. Retrieved from https://www.oecd.org/trade/understanding-the-global-trading-system/why-openmarkets-matter/

Peri, G. (2004). Socio-cultural variables and economic success: evidence from Italian provinces 1951-1991. Topics in macroeconomics, 4(1).

Statista. (2017). Retrieved from https://www.statista.com/outlook/243/101/ecommerce/asia

Townsend, P. (1979). Poverty in the United Kingdom: a survey of household resources and standards of living: Univ of California Press.

UNESCAP. (2016). Updated Analysis of the Broadband Infrastructure in Asia Pacific. Retrieved from https://www.unescap.org/sites/default/files/Updated\%20Analysis\%20of\%20Broadband $\% 20$ Infrastructure\%20in\%20AP_0.pdf 
International Journal of Innovation, Creativity and Change. www.ijicc.net Volume 11, Issue 12, 2020

Wattanakul, T. (2010). Thailand's openness and implications for economic and trade policy: an econometric study. Victoria University,

WorldBank. (2017). Retrieved from https://wits.worldbank.org/analyticaldata/e-trade 